\title{
液相流動床中に垂直に埋設された管群の熱伝達*
}

\author{
橋 詰 健 -*1, 白井光*2 \\ 深 井宏 一*3, 深川晃 弘*3
}

\section{Heat Transfer on Tube Bundles Embedded Vertically in Liquid-Fluidized Beds}

\author{
Kenichi HASHIZUME*4, Akira SHIRAI, \\ Koichi FUKAI and Akihiro FUKAGAWA \\ ${ }^{* 4}$ Department of Intelligent Mechanical Engineering, Hiroshima Institute of Technology, \\ 2-1-1 Miyake, Saeki-ku, Hiroshima-shi, Hiroshima, 731-5193 Japan
}

\begin{abstract}
Bed voidage was measured in liquid-fluidized beds having tube bundles or single tubes embedded vertically in beds, and the heat transfer coefficient was measured on the outer surface of tubes. Test channels used were 6 kinds, and a total of 9 kinds of particles of glass and ceramics were tested. Measured bed voidage agreed well with the correlation developed for the in-column fluidization, when the hydraulic equivalent diameter was used. Measured heat transfer coefficients on the vertically embedded tube bundles were higher than those on the embedded single tubes, the calculated values for the in-column fluidization, and the calculated values for the horizontally embedded tube bundles. Correlations for predicting heat transfer coefficient were derived for the vertically embedded tube bundles and single tubes.
\end{abstract}

Key Words: Multiphase Flow, Fluidized Bed, Bed Voidage, Heat Transfer, Tube Bundle

\section{1. 緒 言}

液相流動床は液単相流に比べて高い熱伝達率を示 し，しかも伝熱面に污れが付きにくいことから多量の 污れ成分を含む液体を対象とした熱交換器への応用が 着目され，一部はすでに実用化段階に入っている(1). 液相流動床 (明膫な床の上縁を有する床型流動床) を応 用する熱交換器の基本構成としては，（1）垂直な伝熱 管の内部に流動床を形成する「管内流動床式」，(2) 床内に伝熱管群を水平に埋設する「床内埋設水平伝熱 管式」，（3) 床内に伝熱管群を垂直に埋設する「床内 埋設垂直伝熱管式」,の3 種類がある(1)。そして前 2 者については熱交換器の熱設計に関連する多くの研究 が蓄積されてきた，例えば，管内流動床式については， ボイド率や熱伝達率に及ぼす壁面の影響(2)(3)，あるい は混合粒子の特性 $(4)(5)$ が明らかになった。床内埋設水 平伝熱管式については，千鳥配列管群(6) および碁盤目 配列管群(7)の伝熱特性が明らかになり，熱伝達率整理

\footnotetext{
* 原稿受付 2008 年 12 月 2 日.

*1 正員, 広島工業大学工学部 (昰 731-5193 広島市佐伯区三宅 2-1-1)

*2 正員，日鋼設計(株) (画736-0082 広島市安芸区船越 1-6-1).

*3 広島工業大学工学部.

E-mail : khshzm@cc.it-hiroshima.ac.jp
}

式も作成された。

しかしながら床内埋設垂直伝熱管式については従来 研究が見当たらない。こ机に注次のふたつのデメリッ 卜の存在が考えられる。そのひとつは，例えば地熱水 のような高圧流体を扱う場合にはシェル側が高圧にな り，熱交換流体が流机る伝熱管に外压がかかることに なるので,シェルも伝熱管も肉厚を厚くしなければな らないことである。そしてもうひとつは下部水室(分 散部) 内と上部水室(バッファー部)内で伝熱管が流動 床に埋設されずこここに污れ成分が蓄積することであ る.しかし床内埋設垂直伝熱管式では流路断面積が大 きいシェル側に流動床が形成されるので多数の伝熱管 を密集配置する熱交換器であっても良好な流動状態が 期待され，しかも熱交換流体との完全対向流が実現で きるので熱交換器としてのメリットは大きい.そこで 本報では液相流動床中に管群(単管を含む)を垂直に埋 設した場合のボイド率扔よび埋設管表面での熱伝達率 を調べ，管内流動床や水平埋設管群との比較を行う。

$$
\begin{gathered}
\text { 記 } \quad \text { 号 } \\
A r: \text { アルキメデス数 }=\left(\rho_{p} / \rho_{L}-1\right) g d_{p}^{3} / \nu_{L}^{2} \\
D_{c} \text { : 管内流動床に扔る流動管の内径 } \\
D_{e} \text { : 流路の水力等価直径 }
\end{gathered}
$$




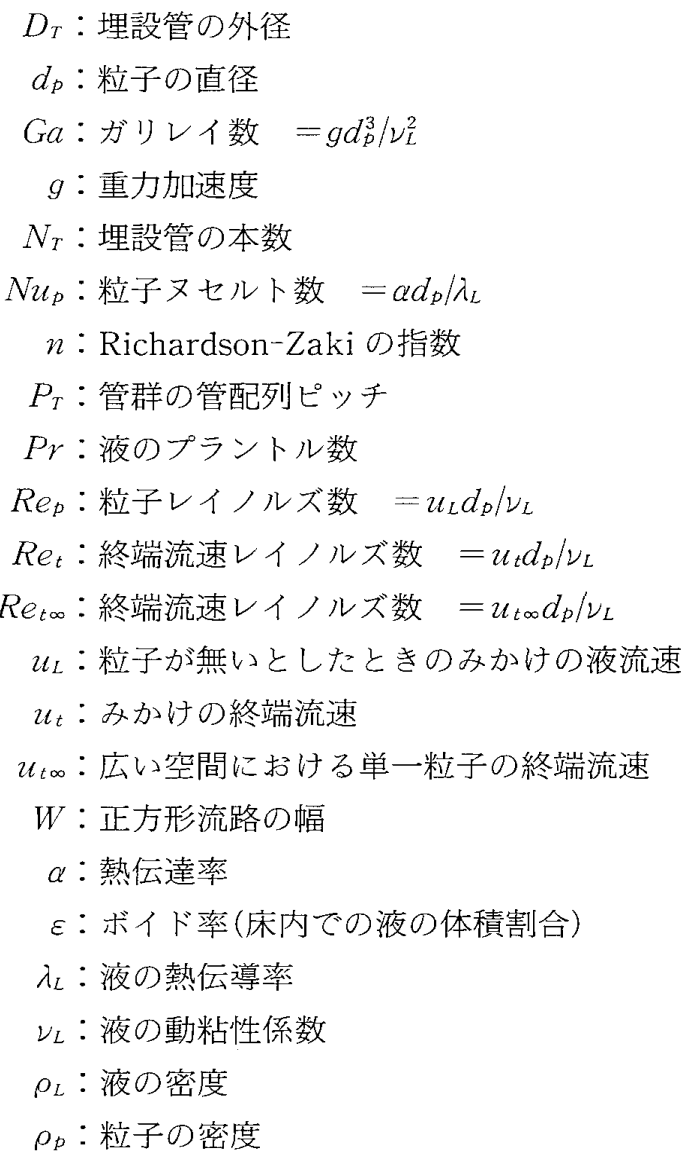

\section{2. 実験}

図 1 に実験装置を示す.タンク（1）に溜められた常 温常压の水はポンプ ( 2)により流量計 ( 3 ), 流量調節 弁 (4), 分散部 (5) を経て試験流路 (6)に送り込まれ る. 分散部には直径 $5 \mathrm{~mm}$ のセラミック球が充填さ れている. 幅 $W$ の正方形断面を持つ試験流路には管 群 $(7)$ が設置され，その中央管は熱伝達率測定管 $(8)$ である、供試粒子が充填された試験流路を通過した水 はバッファー部 $(9)$ を経てタンクに肩る.

試験流路の概略を図 2 に, 寸法を表 1 に示寸. 各試 験流路 (TC)には外径 $D_{T}=19.0 \mathrm{~mm}$ または $25.0 \mathrm{~mm}$ のステンレスパイプ 9 本または 1 本が挿入される.ス テンレスパイプ 9 本は流路内に碁盤目配列し, 流路の 壁は管配列ピッチ $P_{T}$ の中心線上, すなわち $P_{T}=W / 3$ としている。ステンレスパイプは実際の熱交換器に伝 熱管として多用される 3/4-inch 管(外径 $19.05 \mathrm{~mm}$ ) と1-inch 管(外径 $25.4 \mathrm{~mm}$ )に近い寸法として選定し た。また，実際の熱交換器では管板の強度や伝熱管と の溶接性から $P_{T} / D_{T}>1.25$ が一般的であるが, ここで は極限までの状態を調べる目的で $P_{T} / D_{T}=1.20$ (TC6)についての実験も行う. 各試験流路の中央管(図 2 の網掛け管) は熱伝達率測定管で, 図 3 にその詳細を 示す.これはカートリッジヒーターに銅製スリーブ

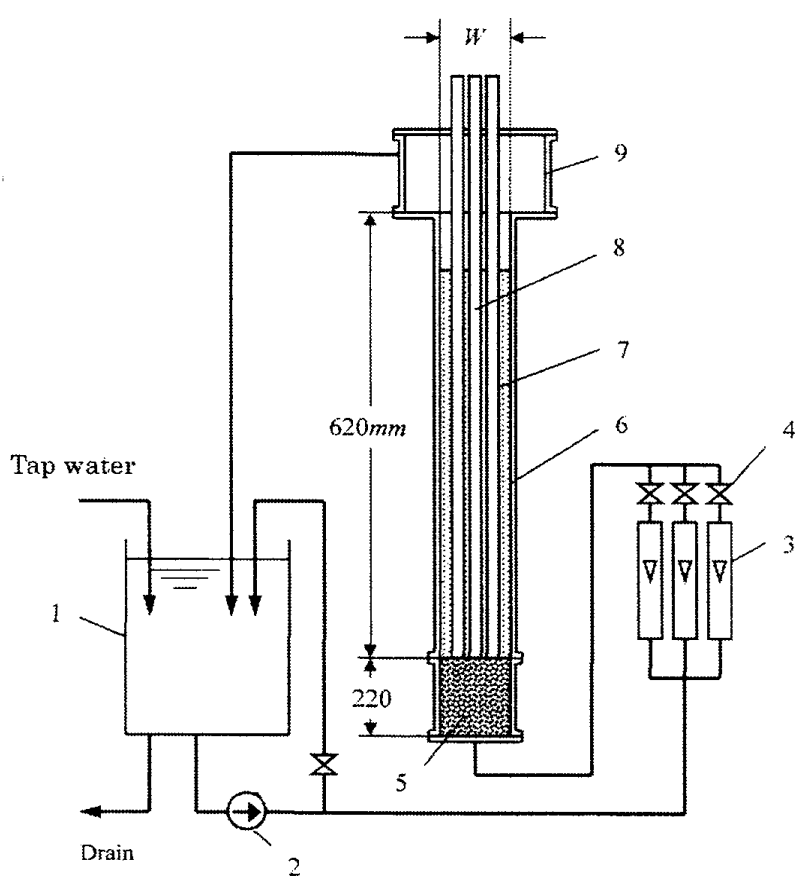

1: Water tank 2:Pump 3:Flowmeter 4:Control valve

5: Distribution section 6: Test channel 7 : Tube bundle 8: Heat transfer measuring tube 9: Buffer section

Fig. 1 Experimental apparatus

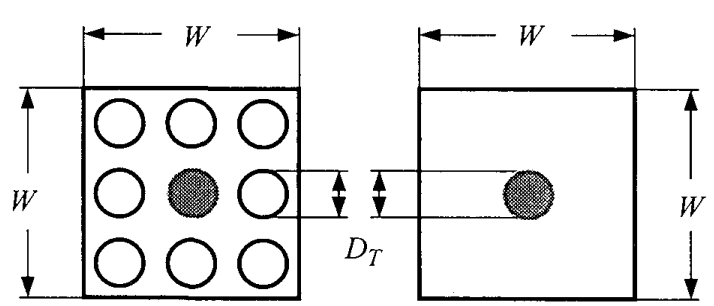

TC-1, 4, 6

TC-2, 3, 5

Fig. 2 Test channel

（肉厚 $2 \mathrm{~mm}$ ）を嵌め込み，上下両端をべークライト製 断熱筒を介してステンレスパイプに接続したもので, 銅製スリーブの中央部表面には周方向 4 箇所にシース 外径 $0.5 \mathrm{~mm}$ の $\mathrm{T}$ 型熱電対を埋め込んである. 発熱 部長さ $L_{T}$ は, $D_{T}=19.0 \mathrm{~mm}$ では $L_{T}=80 \mathrm{~mm}, D_{T}=$ $25.0 \mathrm{~mm}$ では $L_{T}=100 \mathrm{~mm}$ である。

表 2 に供試粒子と粒子番号(Pno.)を示す。供試粒 子はガラス球とセラミック球の合計 9 種類である. 表 1 には試験流路と供試粒子との組合せによる実験番号 (Tno.)も示してある.

\section{3. ボイド率の実験結果}

ボイド率の測定は試験流路 TC-1, 2, 3 用いて行 い, ボイド率は充填する粒子の量と床高さから算出し た。 
Table 1 Test channel configuration and test condition

\begin{tabular}{|c|c|c|c|c|c|c|c|}
\hline \multicolumn{2}{|c|}{ Test channel } & TC-1 & TC-2 & TC-3 & TC-4 & TC-5 & TC-6 \\
\hline \multicolumn{2}{|c|}{$D_{T}, \mathrm{~mm}$} & \multicolumn{2}{|c|}{19.0} & \multicolumn{4}{|c|}{25.0} \\
\hline \multicolumn{2}{|c|}{$W, \mathrm{~mm}$} & \multicolumn{3}{|c|}{75.0} & \multicolumn{2}{|c|}{100.0} & 90.0 \\
\hline \multicolumn{2}{|c|}{$N_{T}$} & 9 & 1 & 1 & 9 & 1 & 9 \\
\hline \multicolumn{2}{|c|}{$D_{e}, \mathrm{~mm}$} & 22.9 & 59.4 & 54.3 & 31.6 & 79.5 & 20.8 \\
\hline \multirow{9}{*}{ Particle } & Pno. 51 & Tno. 1-51 & Tno. 2-51 & Tno. 3-51 & & & \\
\hline & Pno. 52 & Tno. 1-52 & Tno. 2-52 & Tno. 3-52 & Tno. 4-52 & & \\
\hline & Pno. 53 & & Tno. 2-53 & Tno. 3-53 & & & \\
\hline & Pno. 54 & & Tno. 2-54 & Tno. 3-54 & Tno. 4-54 & & \\
\hline & Pno. 55 & & Tno. 2-55 & Tno. 3-55 & & & \\
\hline & Pno. 56 & & Tno. 2-56 & Tno. 3.56 & & & \\
\hline & Pno. 61 & Tno. 1-61 & Tno. 2-61 & Tno. 3-61 & Tno. 4-61 & & Tno. 6-61 \\
\hline & Pno. 62 & Tno. 1-62 & Tno. 2-62 & Tno. 3-62 & Tno. 4-62 & Tno. 5-62 & Tno. 6-62 \\
\hline & Pno. 63 & & Tno. 2-63 & Tno. 3-63 & Tno. 4-63 & & \\
\hline
\end{tabular}

Table 2 Tested particles

\begin{tabular}{|c|c|c|c|c|}
\hline $\begin{array}{l}\text { Particle } \\
\text { number }\end{array}$ & Material & $\begin{array}{c}\text { Density } \\
\rho_{p}, \mathrm{~kg} / \mathrm{m}^{3}\end{array}$ & $\begin{array}{l}\text { Diameter } \\
d_{p}, \mathrm{~mm}\end{array}$ & $\begin{array}{c}\text { Archimedes } \\
\text { number* }^{*} A r\end{array}$ \\
\hline Pno. 51 & \multirow{6}{*}{ Glass } & \multirow{6}{*}{2530} & 2.19 & $1.62 \times 10^{5}$ \\
\hline Pno. 52 & & & 2.69 & $2.99 \times 10^{5}$ \\
\hline Pno. 53 & & & 3.98 & $9.70 \times 10^{5}$ \\
\hline Pno. 54 & & & 4.95 & $1.87 \times 10^{6}$ \\
\hline Pno. 55 & & & 5.98 & $3.29 \times 10^{6}$ \\
\hline Pno. 56 & & & 6.95 & $5.17 \times 10^{6}$ \\
\hline Pno. 61 & \multirow{3}{*}{ Ceramics } & \multirow{3}{*}{3700} & 2.10 & $2.51 \times 10^{5}$ \\
\hline Pno. 62 & & & 3.15 & $8.48 \times 10^{5}$ \\
\hline Pno. 63 & & & 4.02 & $1.76 \times 10^{6}$ \\
\hline
\end{tabular}

* Water at $20^{\circ} \mathrm{C}$

$3 \cdot 1$ 静止床のボイド率＼cjkstart粒子を流動化させたの ち液流量を緩やかに減少させて流動化が停止したとき のボイド率として定義される静止床のボイド率 $\varepsilon_{m f}$ に対しては，管内流動床の実験に基づいて橋詰ら ${ }^{(2)}$ が 次の実験整理式を導いている.

$$
\varepsilon_{m f}=0.46+0.03 \log _{10}\left(\frac{d_{p}}{D_{c}}\right)
$$

図 4 は実験結果を式 $(1)$ と比較したもので，実験点 (白抜印) は式(1)による計算值 (実線)と良く一致して いる. 但し, 式 $(1)$ における流動管内径 $D_{c}$ は試験流 路の水力等価直径 $D_{e}$ に置き換えている. 管群 $(\mathrm{TC}-$ 1)に対しては，管配列ピッチ $P_{T}$ の 4 本の管に囲まれ るひとつの流路(サブチャンネル)の水力等価直径

$$
D_{e}=\frac{4\left(P_{T}^{2}-\frac{\pi}{4} D_{T}^{2}\right)}{\pi D_{T}}
$$

を用いた。単管(TC-2，3）においてはサブチャンネル が存在しないので, 流路全体の水力等価直径

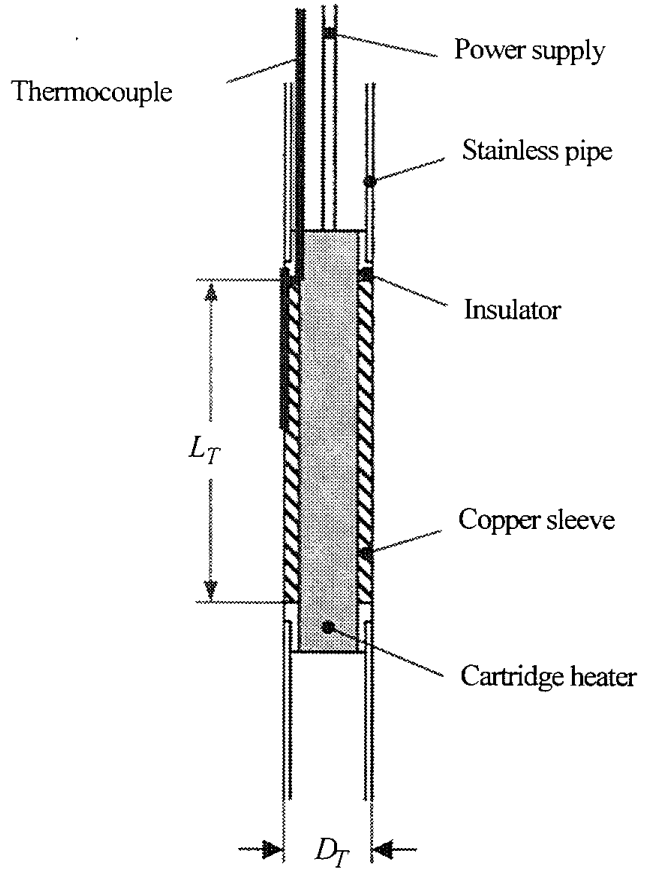

Fig. 3 Heat transfer measuring tube 


$$
D_{e}=\frac{4\left(W^{2}-\frac{\pi}{4} D_{T}^{2}\right)}{\pi D_{T}+4 W}
$$

を用いた。

\section{$3 \cdot 2$ 流動床のボイド率＼cjkstart流動床のボイド率} 多くの場合, 次の Richardson-Zaki の関係式によっ て整理される。

$$
\frac{R e_{p}}{R e_{t}}=\varepsilon^{n}
$$

ここで $R e_{t}$ はみかけの終端流速 (レイノルズ数)で, ボ イド率の実験データを液流速に対して両対数グラフ上 に表示したとき，実験点を貫く直線が $\varepsilon=1$ と交わる 液流速 (粒子レイノルズ数 $\left.R e_{p}\right)$ として定義されるが, これは壁面の影響を受けて変化する。また, Richard son-Zaki の指数 $n$ も壁面の影響を受けるので, 橋詰 $ら^{(2)}$ は管内流動床の実験に基づいて次の実験整理式

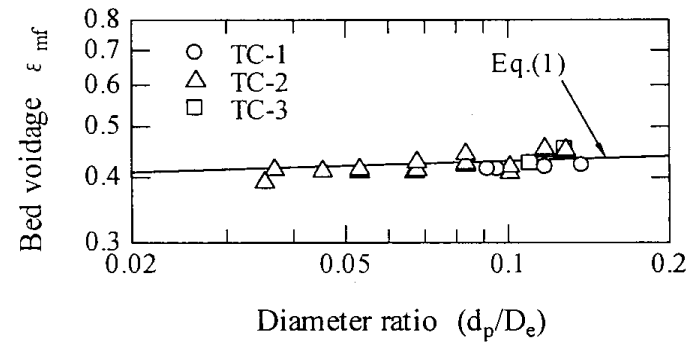

Fig. 4 Bed voidage at minimum fluidization
を導いた。

$$
\begin{aligned}
& \frac{R e_{t}}{R e_{t \infty}}=1-0.75\left(\frac{d_{p}}{D_{c}}\right)^{0.4} \\
& \frac{n}{n_{\infty}}=1-0.75\left(\frac{d_{p}}{D_{c}}\right)
\end{aligned}
$$

ここでR $e_{t \infty}$ は広い空間における単一粒子の終端流速 レイノルズ数 ${ }^{(8)}, n_{\infty}$ は広い空間における Richardson-Zaki の指数(9) である。図 5 は実験結果を式(4), （5）による計算值(右上がりの実線）と比較したもの で，両者はよく一致している，図 5 には式(1)による 静止床のボイド率 $(\varepsilon=0.42$ 付近の水平な実線 $)$ 示し て扔り, 静止床のボイド率と流動床のボイド率との交 点が次式(10) で表わされる流動開始レイノルズ数 $R e_{m f}$ になる。

$$
\begin{aligned}
& R e_{m f}=\left[C_{1}^{2}+C_{2} A r\right]^{0.5}-C_{1} \\
& C_{1}=\frac{300}{7}\left(1-\varepsilon_{m f}\right) \\
& C_{2}=\frac{\varepsilon_{m f}^{3}}{1.75}
\end{aligned}
$$

但し，式（5）に打ける流動管内径 $D_{c}$ は式（2），(3) による水力等価直径 $D_{e}$ に置き換えている.

図 4 および図 5 より，垂直に埋設された管群(単管 を含む)を有する流動床のボイド率に対しては水力等

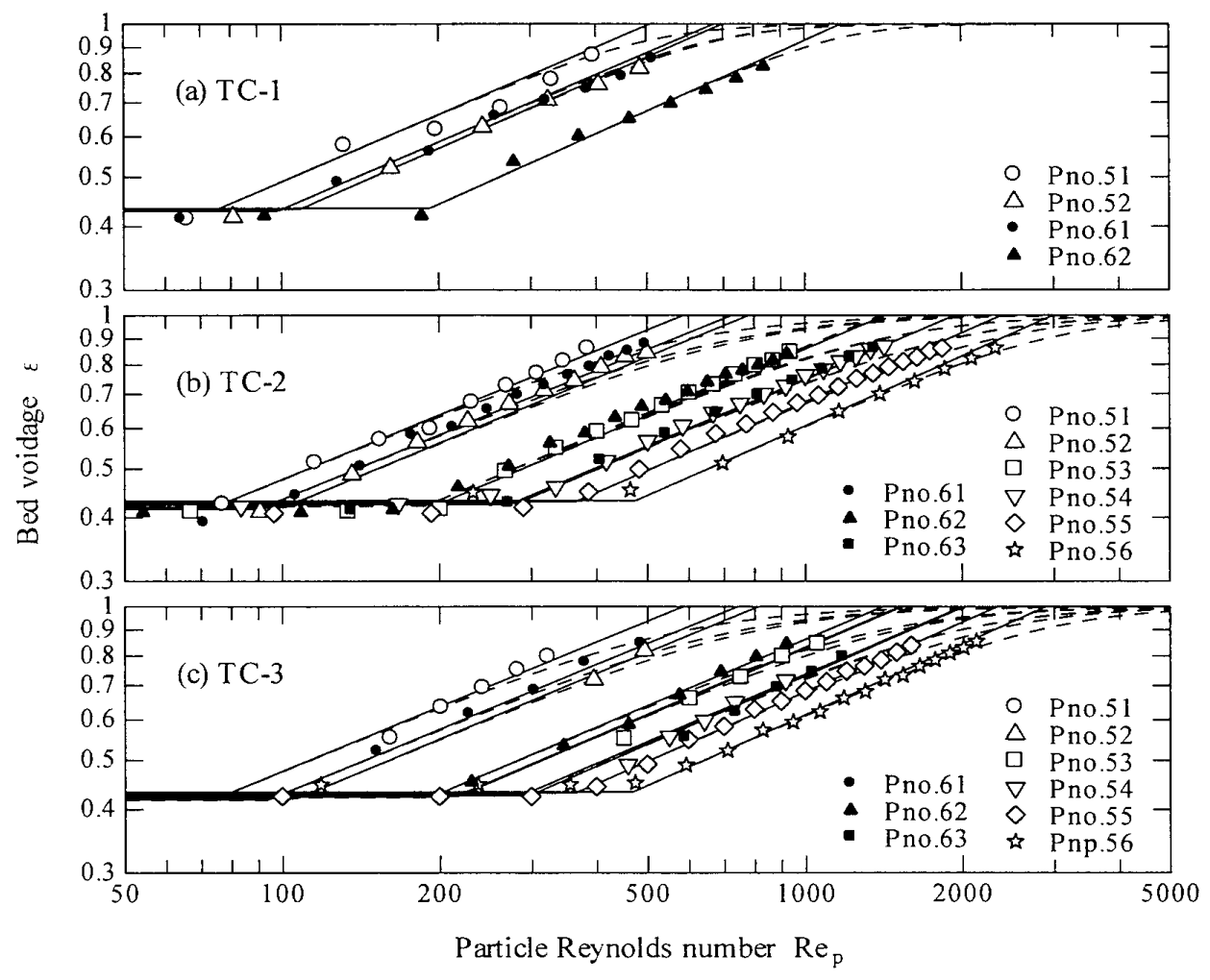

Fig. 5 Experimental results of bed voidage 
価直径を用いれば管内流動床の実験から導かれた整理 式が適用できることがわかった。

なお，ボイド率を図 5 のように両対数グラフ上に表 示したとき，高ボイド率領域 $(\varepsilon>0.85)$ では粒子レイ ノルズ数に対するボイド率の変化は直線から離れて $\varepsilon \rightarrow 1$ で $e_{t \infty}$ に漸近することが知られている。ボイ ド率を床高さの測定から算出する本実験に拉いては高 ボイド率領域のデータを収集することが困難なので， この領域のボイド率は 4 章の熱伝達率の実験結果から 推定した。図 5 中の破線は後述する式(9), (19), (20)による計算値を示している.

\section{4. 熱伝達率の実験結果}

熱伝達率測定管まわりの平均熱伝達率 $\alpha$ は次式に より算出した.

$$
\alpha=\frac{Q /\left(\pi D_{T} L_{T}\right)}{T_{w, m}-T_{L}}
$$

ここで $Q$ は熱伝達率測定管(カートリッジヒータ 一) の電気入力, $L_{T}$ は熱伝達率測定管の発熱部長 さ， $T_{w, m}$ は 4 箇所の熱電対による測定温度に熱伝導 方程式を用いて算出した熱伝達率測定管(銅製スリー ブ）の表面平均温度， $T_{L}$ は試験流路の上下で測定した 水温の平均値である.

$4 \cdot 1$ 既存整理式との比較 垂直理設管群に類似 する管内流動床については橋詰(11)による次式がある。

$$
\begin{aligned}
& N u_{p}=0.037 \operatorname{Re}_{t}^{0.44} \operatorname{Pr}^{1 / 3} G a^{1 / 6} \\
& \quad \times\left[(1-\varepsilon)^{0.56} \varepsilon^{0.44 n}\right]\left(\frac{D_{c}}{l_{c}}\right)^{1 / 4} \\
& l_{c}=\left(\frac{\nu_{L}^{2}}{g}\right)^{1 / 3}
\end{aligned}
$$

ここでボイド率 率を $\varepsilon_{\mathrm{cal}}$ として, 次式により高ボイド率領域の補正を 行う.

$$
\begin{aligned}
& \varepsilon^{-m}=\varepsilon_{\mathrm{cal}}^{-m}+1 \\
& m=5\left[1+2\left(\frac{d_{p}}{D_{c}}\right)\right]
\end{aligned}
$$

式(9)は，ボイド率が大きくなれば液流速(粒子レイ ノルズ数)に対するボイド率の変化が直線から離れる 傾向を表わし，指数 $m$ は熱伝達率の実験結果加ら定 められた。そして, 式（８）による流動床の熱伝達率が 液単相流の值を下回ったときには，粒子が流出した液 単相流の状態とみなしている。そのほかに，種々の伝 熱面形状に対して適用できるとされている次の Haid ら(12)の式もよく知られている.

$$
N u_{p}=0.1493 \operatorname{Re}_{p}^{0.72} \operatorname{Pr}^{0.52}
$$

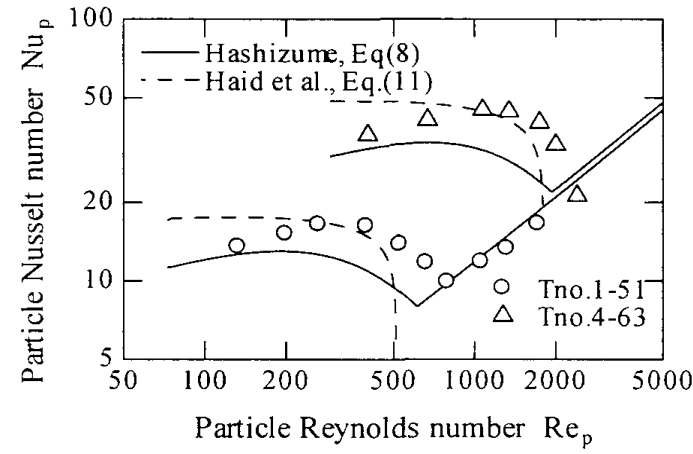

Fig. 6 Comparison with existing correlations

$$
\times\left[(1-\varepsilon)^{0.19} \varepsilon^{-1.41}\right]\left(\frac{\rho_{p}-\rho_{L}}{\rho_{L}}\right)^{0.03}\left(\frac{d_{p}}{D_{e}}\right)^{1 / 4}
$$

図 6 は管群 $(\mathrm{TC}-1,4)$ の実験結果 (白抜印, 実験番号 Tno. は表 1 に対応) と橋詰の方法 [式(8)，実線］お よびHaidらの整理式 [式(11), 破線]との比較を示 したものである.但し, 試験流路 TC-1，4のような形 状における液単相流の熱伝達率計算方法は見当たらな いので，ここでは管内流路の熱伝達率計算式 ${ }^{(13)}$ にお いて管内径を水力等価直径に置き換えて計算してい る.また，計算値は式 $(6)$ にる流動開始レイノルズ 数 $R e_{m f}$ 以降の值を描いている.

図 6 をみる, 橋詰の方法(実線) は液流速 $\left(R e_{p}\right) に$ 対する熱伝達率 $\left(N u_{p}\right)$ の変化の傾向は実験結果に近い が, 小さ目の值を予測している。また, Haidらの整 理式(破線)では最大熱伝達率はほぼ一致しているもの の, $R e_{p}$ に対する $N u_{p}$ の変化の傾向が実験結果と異 なっている.そこで, 式 ( 8)〜 (10)を作成したと同様 の手法により垂直埋設管群(単管を含む)の熱伝達率整 理式を作成する。

$4 \cdot 2$ 熱伝達率整理式の作成 式 (8) は管内流動 床の熱伝達率実験デー夕を $j$ 因子

$$
\begin{aligned}
& j=S t P r^{2 / 3} \\
& S t=\frac{N u_{p}}{R e_{p} P r}
\end{aligned}
$$

で表わし，これを修正レイノルズ数

$$
R e_{h}=\frac{R e_{p}}{1-\varepsilon}
$$

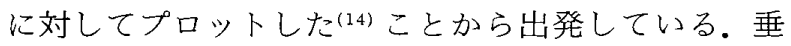
直埋設管群についても同様の表示を試みるが, 粒子直 径の影響は式(8)のガリレイ数 $G a$ で表わされるもの として, $j$ 因子の代わりに修正 $j$ 因子 $j_{m}$

$$
j_{m}=\frac{S t P r^{2 / 3}}{G a^{1 / 6}}
$$

をとって表示した結果が図 7 である。ここでボイド率 


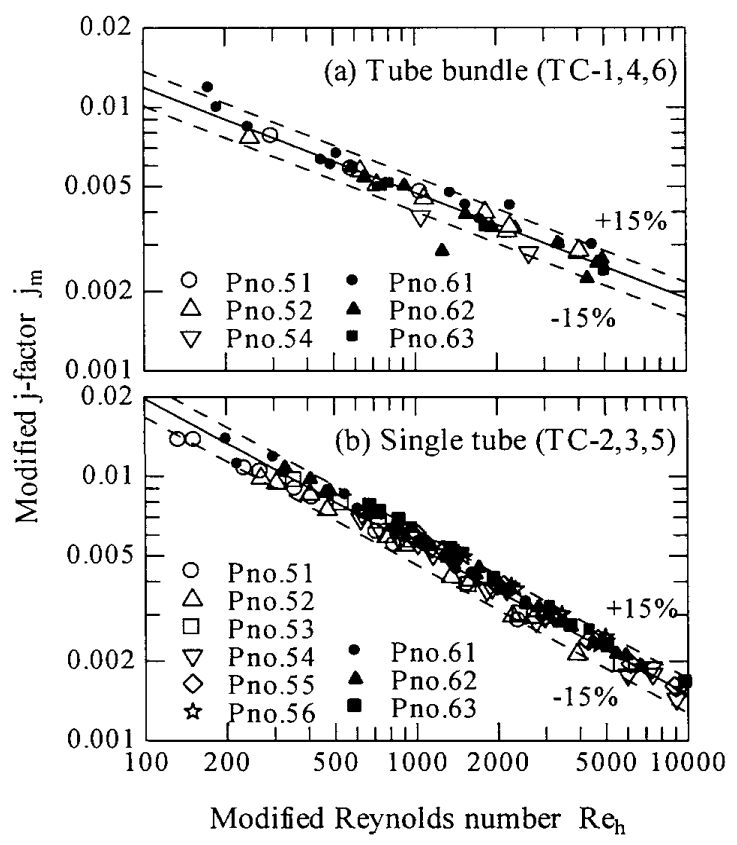

Fig. 7 Modified $j$-factor vs. modified Reynolds number

$\varepsilon$ は式(4), (5)により算出し, 高ボイド率領域 $(\varepsilon>$ $0.85)$ のデータは除いている. 図 7(a)の管群と図 7 (b)の単管では明らかに傾向が異なっているが, 粒 子の種類や埋設管外径の影響は認められない. 実験点 は

$$
\begin{aligned}
& j_{m}=0.075 R e_{h}^{-0.40}: \text { 管群 } \\
& j_{m}=0.26 R e_{h}^{-0.56}: \text { 単管.. }
\end{aligned}
$$

で表わされる。ここに Richardson-Zakiの関係式 （4）を用いれば，管群については式(15)より

$$
\begin{aligned}
& N u_{p}=0.075 \operatorname{Re}_{t}^{0.60} \mathrm{Pr}^{1 / 3} \mathrm{Ga}^{1 / 6} \\
& \quad \times\left[(1-\varepsilon)^{0.40} \varepsilon^{0.60 n}\right] \cdots \cdots \cdots \cdots
\end{aligned}
$$

単管については式(16)より

$$
\begin{aligned}
& N u_{p}=0.26 \operatorname{Re}_{t}^{0.44} \mathrm{Pr}^{1 / 3} G a^{1 / 6} \\
& \quad \times\left[(1-\varepsilon)^{0.56} \varepsilon^{0.44 n}\right] \cdots \ldots \ldots . .
\end{aligned}
$$

が得られる。

次いで, 式 (9)に㧍ける高ボイド率領域に対する補 正指数 $m$ を実験データとの比較から求める.この目 的のために図 7 で対象外とした高ボイド率領域 $(\varepsilon>$ 0.85)のデータをも加えたすべての実験デー夕を図 6 のように表示し, 式(17)，（18)が最も良く実験点を再 現する補正指数 $m$ を各実験条件について求めたとこ ろ図 8 のようになった。これらの值は管群 $(\mathrm{TC}-1,4$, 6)については

$$
m=15\left(\frac{d_{p}}{D_{e}}\right)^{0.2}
$$

単管 $(\mathrm{TC}-2,3,5)$ につては

$$
m=8.7\left(\frac{d_{p}}{D_{e}}\right)^{0.1}
$$

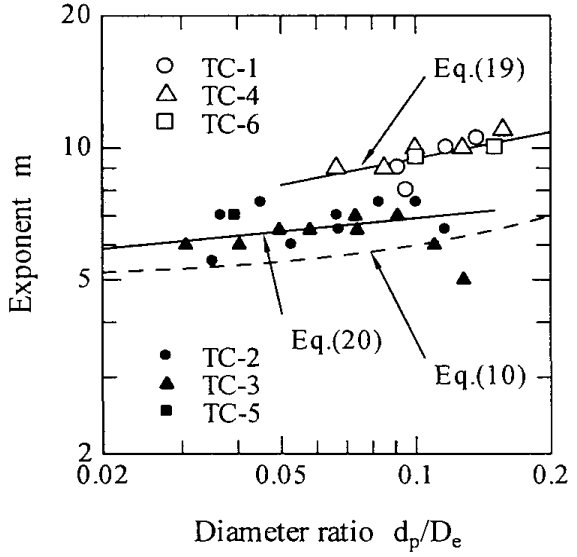

Fig. 8 Exponent $m$ in Eq. (9)

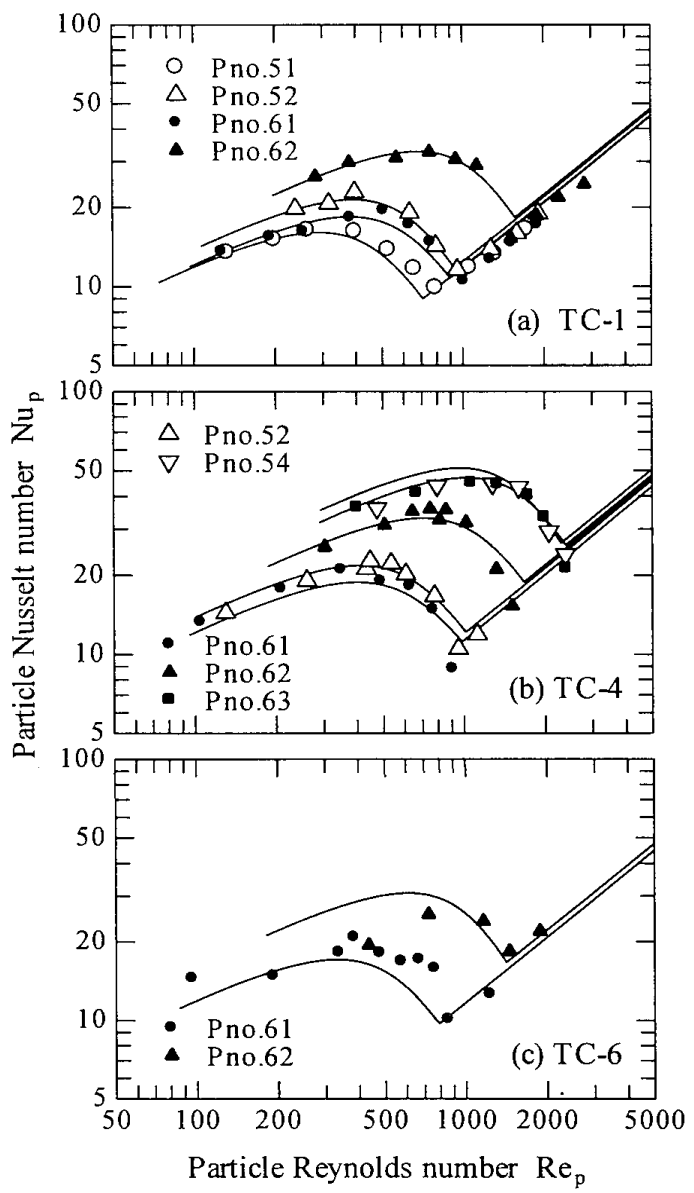

Fig. 9 Experimental results on tube bundles

として表わされる。図 8 中の破線は管内流動床に対す る式(10)の值であるが，式(19)，(20)の值はこれより も大きくなっている.これは，垂直埋設管群では管内 流動床よりも大きな液流速までボイド率が直線的に変 化することを意味している。図 5 中の破線は式(19)， （20）を考慮したボイド率の計算値を示している.

図 9 は垂直埋設管群の実験データと式 (17) との比較 である.図 9(a) は試験流路 $\mathrm{TC}-1\left(D_{T}=19 \mathrm{~mm}, W\right.$ 


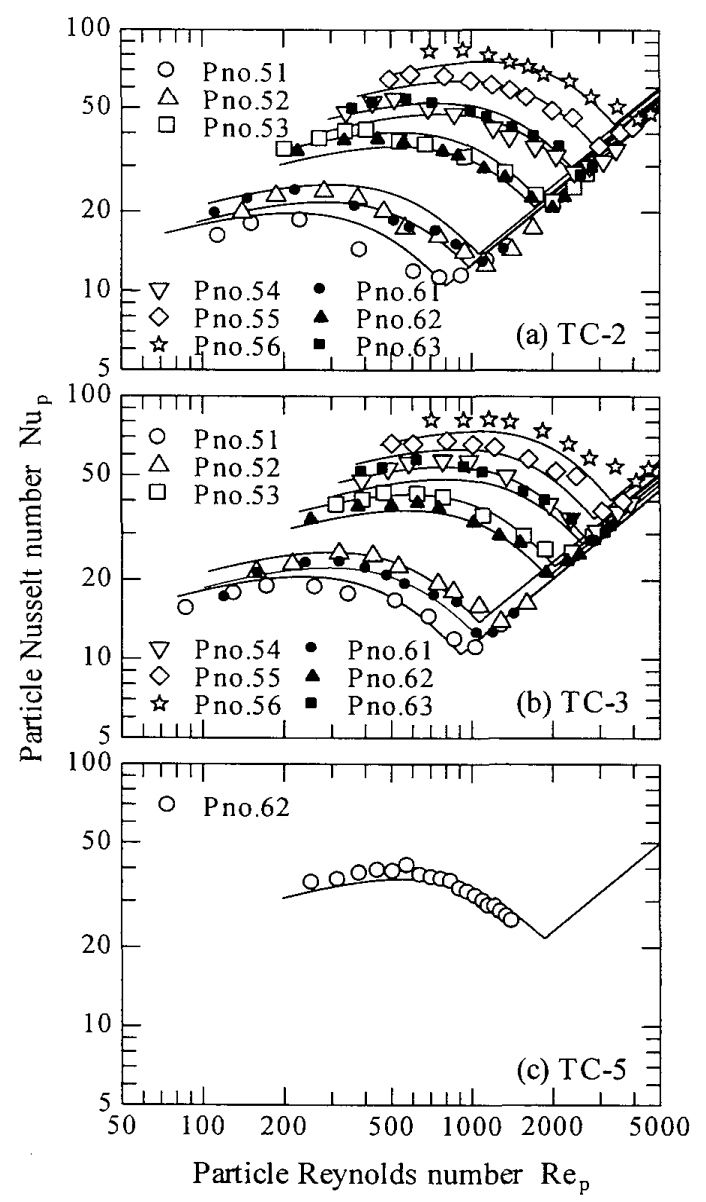

Fig. 10 Experimental results on single tubes

$\left.=75 \mathrm{~mm}, P_{T} / D_{T}=1.32\right)$ のデータ, (b)は試験流路 $\mathrm{TC}-4\left(D_{T}=25 \mathrm{~mm}, W=100 \mathrm{~mm}, P_{T} / D_{T}=1.33\right)$ のデ ータで, 実線で示した式(17)による計算值とよく一致 している．図 $9(\mathrm{c})$ は配管ピッチを極限まで狭めた試 験流路 TC-6 $\left(P_{T} / D_{T}=1.20\right)$ に打けるデー夕で, この 場合には粒子の動きが極端に悪く，熱伝達率デー夕に ばらつきが大きい。この結果より熱交換器としての実 用範囲は $P_{T} / D_{T}>1.32$ といえよう。なお, 図 $9(\mathrm{a}) \sim$ (c)における右上がりの直線は液単相流の管内流路に 対する熱伝達率計算式(13) に扔いて管内径を水力等価 直径に置き換えて計算した值であり，これも実験デー タと良く一致している。

図 10 は垂直埋設単管の実験デー夕を式(18)と比較 したもので（a ～（c）いずれにおいても実線で示し た式(18)による計算值とよく一致している.

$4 \bullet 3$ 熱伝達率の比較 伝熱管群を水平に埋設す る水平埋設管群の熱伝達率に対して橋詰(1) に類似して

$$
\begin{aligned}
& N u_{p}=1.05 \operatorname{Re}_{t}^{0.44} \operatorname{Pr}^{1 / 3} G a^{1 / 6} \\
& \quad \times\left[(1-\varepsilon)^{0.56} \varepsilon^{0.44 n}\right]\left(\frac{D_{T}}{l_{c}}\right)^{-1 / 4}
\end{aligned}
$$

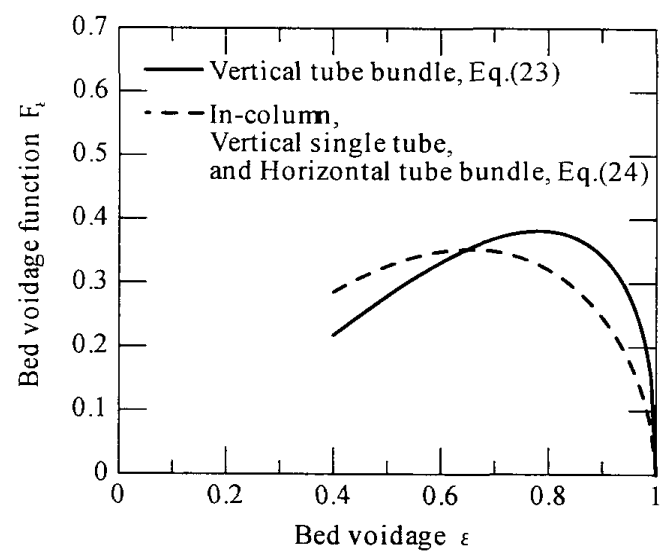

Fig. 11 Bed voidage function

を与えており,これら式(8)や式(21)は

$$
N u_{p}=F_{s} \cdot F_{\varepsilon}
$$

の形を有しているこここで $F_{s}$ はシステム係数で, 流 動床の系(流路や伝熱面の寸法形状，扝よび粒子と流 動化流体）により定まり，最大熱伝達率を支配する。 $F_{\varepsilon}$ はボイド率関数で, ボイド率変化に対する熱伝達 率変化の傾向を表わす。

ボイド率関数 $F_{\varepsilon}$ は垂直埋設管群については式(17) より

$$
F_{\varepsilon}=(1-\varepsilon)^{0.40} \varepsilon^{0.60 n}
$$

管内流動床, 垂直埋設単管, 水平埋設管群については 式(8)，(18)，(21)上り

$$
F_{\varepsilon}=(1-\varepsilon)^{0.56} \varepsilon^{0.44 n}
$$

となる. 図 11 はボイド率関数 $F_{\varepsilon}$ の值を示したもの で，此較を簡単化するために Ricahrdson-Zaki の指 数 $n$ 及济す壁面の影響を省略して $n=n_{\infty}=2.4(\mathrm{Ar}$ > $\left.10^{5}\right)$ としている. 垂直埋設管群 (実線)ではボイド率変 化に対する熱伝達率の変化が他の系(破線)に比べて急 になっていることがわかる，また，最大值は，他の系 では $\varepsilon=0.65$ で最大值 $F_{\varepsilon, \max }=0.353$ 亿なっているの に対して, 垂直埋設管群では $\varepsilon=0.78$ で最大值 $F_{\varepsilon, \max }$ $=0.382$ を示している.

最大熱伝達率は式 (22)より

$$
N u_{p, \text { max }}=F_{s} \cdot F_{\varepsilon, \text { max }}
$$

となる．これを同一流体で同一直径粒子について比較 するために

$$
N u_{p, \max }^{*}=\frac{N u_{p, \max }}{P r^{1 / 3} G a^{1 / 6}}=F_{s}^{*} \cdot F_{\varepsilon, \max }
$$

とすれば，F゙はそれぞれの系に対して式(17)，(18)， (8)，(21)より次のようになる。

$F_{s}^{*}=0.075 R e_{t}^{0.60}$ : 垂直埋設管群

$F_{s}^{*}=0.26 R e_{t}^{0.44}$ : 垂直埋設単管 


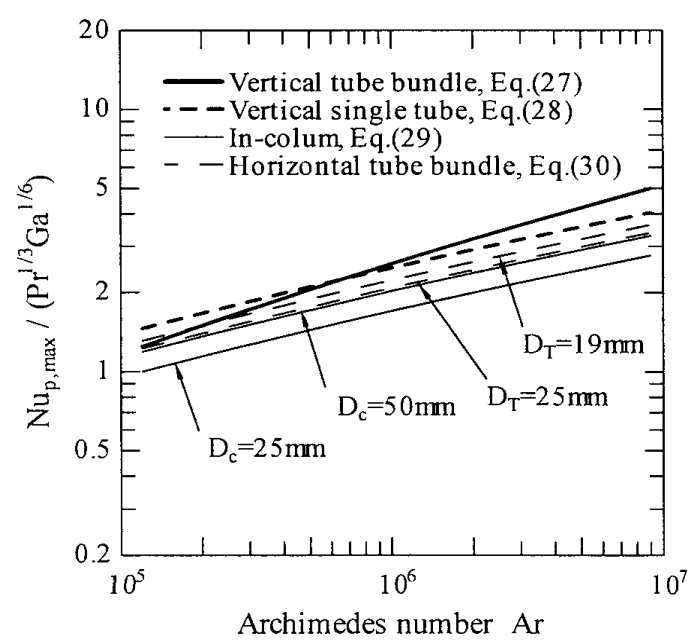

Fig. 12 Maximum heat transfer coefficientin form of Eq. (26)

$$
\begin{aligned}
& F_{s}^{*}=0.037 \operatorname{Re}_{t}^{0.44}\left(\frac{D_{c}}{l_{c}}\right)^{1 / 4}: \text { 管内流動床 } \cdots . . \\
& F_{s}^{*}=1.05 \operatorname{Re}_{t}^{0.44}\left(\frac{D_{T}}{l_{c}}\right)^{-1 / 4}: \text { 水平埋設管群 }
\end{aligned}
$$

最大熱伝達率を式(26)の形で比較したのが図 12 で ある.ここでも比較を簡単化するために端流速レイノ ルズ数 $R e_{t}$ に及ぼす壁面の影響を省略して $R e_{t}=$ $R e_{t \infty}$ とし, Re $e_{t \infty}$ をルキメデス数で表わしている. 図 12 より,垂直埋設管群 (太実線)の最大熱伝達率は Ar $>6.5 \times 10^{5}$ では他の系よりも大きいことがわか る.金直埋設単管 (太破線) はこれに次ぐ、管内流動床 (細実線) は流動管内径の影響を受け, 本実験の範囲 $\left(D_{e}<80 \mathrm{~mm}\right)$ では垂直埋設単管の值を下回る. 水平 埋設管群(細破線)も埋設管外径の影響を受けるが, 本 実験と同一外径の管 $\left(D_{T}=19,25 \mathrm{~mm}\right)$ を埋設した場 合には垂直埋設管群の值を下回る。

以上の比較により, 垂直埋設管群では管内流動床や 水平埋設管群よりも大きな熱伝達率が得られ，しかも より大きなボイド率で最大熱伝達率が得られる特徴が あることがわかった。特に後者の特徵は最大熱伝達率 を運転条件とする熱交換器への応用において充填する 粒子の量が少なくてすむことを意味しており，緒言で 述べた「床内埋設垂直伝熱管式」が他の形式に比べて 有利であることが示されたといえる。

\section{5. 結言}

液相流動床中に管群(単管を含む)を垂直に埋設した 場合のボイド率と埋設管表面での熱伝達率を調べ, 管 内流動床や水平埋設管群と比較した。その結果は実験
範囲内で次のように要約される。

（1）ボイド率については, 流路の水力等価直径を 用いれば垂直埋設管群, 垂直埋設単管ともに管内流動 床の実験より導かれた式 $(4) ，(5)$ が適用できる.

（2）熱伝達率については, 垂直埋設管群, 垂直埋 設単管それぞれに対して実験整理式として式(17) およ び式(18)を導いた。

（3）熱伝達率は垂直埋設管群, 垂直埋設単管とも に埋設管外径の影響を受けない。

（4）最大熱伝達率を与えるボイド率は，垂直埋設 管群では他の系 (垂直埋設単管, 管内流動床, 水平埋設 管群)よりも大きい.

（5）最大熱伝達率も垂直埋設管群が他の系よりも 大きい.

本研究により流動床を応用する「床内埋設垂直伝熱 管式」熱交換器の熱設計が可能になった，垂直埋設管 群の熱伝達率は管内流動床や水平埋設管群よりも大き く，しかも最大熱伝達率を与えるボイド率が大きいの で, 設計条件において大流量の流動化流体を扱うこと ができて粒子充填量も削減できるなど床内埋設垂直伝 熱管式熱交擙器の有利性が示された。

なお，本研究における試験流路 TC-4, TC-6につい ての実験では川本晃大君 [現：中電プラント(株)］と 藤原鉄也君 [現：今治造船(株)］の協力を得たことを 記して感謝の意を表する。

\section{文献}

(1) Hashizume, K., Flow and Heat Transfer in LiquidFluidized Bed: Part 1, Science of Machine, Vol.60, No. 8 (2008), pp. 872-878, in Japanese.

(2) Hashizume, K. and Matsue, T., Effect of Wall on Void Fraction of Liquid-Fluidized Beds, Transactions of the Japan Society of Mechanical Engineers, Series B, Vol. 63, No. 612 (1997), pp. 2797-2802, in Japanese.

(3) Hashizume, K. and Matsue, T., Heat Transfer in Liquid-Fluidized Beds affected by Column Wall, Transactions of the Japan Society of Mechanical Engineers, Series B, Vol.64, No. 628 (1998), pp. 4172-4178, in Japanese.

(4) Hashizume, K. and Matsue, T., Characteristics of Particle Mixtures in a Liquid-Fluidized Bed, Transactions of the Japan Society of Mechanical Engineers, Series B, Vol.64, No.623 (1998), pp. 2280-2285, in Japanese.

(5) Hashizume, K., Tokutome, A. and Matsue, T., Heat Transfer Characteristics of Liquid-Fluidized Beds Using Homogeneously-Mixable Particle Mixtures in Fluidizing Column, Transactions of the Japan Society of Mechanical Engineers, Series B, Vol.68, No.671 (2002), pp. 2098-2105, in Japanese.

(6) Hashizume, K. and Shirai, A., Heat Transfer on Tube Bundles Embedded Horizontally in a Liquid-Fluidized Bed, Transactions of the Japan Society of Mechanical 
Engineers, Series B, Vol. 70, No. 696 (2004), pp. 21102116, in Japanese.

(7) Hashizume, K., Onji, R., Niiki, S., Tsukuda, H. and Yoshida, R., Heat Transfer on Tube Bundles Embedded Horizontally in a Liquid-Fluidized Bed (2nd Report, On Tube Bundles of Fundamental Layouts Including In-Line Layouts), Transactions of the Japan Society of Mechanical Engineers, Series B, Vol. 74, No. 744 (2008), pp. 1799-1806, in Japanese.

(8) Hartman, M., Havlin, V., Trnka, O. and Carsky, M., Predicting the Free-Fall Velocities of Spheres, Chemical Engineering Science, Vol.44, No. 8 (1989), pp. 1743-1745.

(9) Khan, A. R. and Richardson, J. F., Fluid-Particle Interactions and Flow Characteristics of Fluidized Beds and Settling Suspensions of Spherical Particles, Chemical Engineering Communications, Vol.78 (1989), pp.111130 .
(10) Hashizume, K., Flow and Heat Transfer in LiquidFluidized Bed: Part 2, Science of Machine, Vol.60, No. 9 (2008), pp. 979-984, in Japanese.

(11) Hashizume, K., An Approach to Develop a Correlation for Liquid-Fluidized Bed Heat Transfer, Chemical Engineering and Processing, Vol. 45 (2006), pp.9901000.

(12) Haid, M., Martin, H. and Steinhagen, H. M., Heat Transfer to Liquid-Solid Fluidized Beds, Chemical Engineering and Processing, Vol. 33 (1994), pp. 211225.

(13) VDI-Waermeatlas, 9. Auflage, (2002), Ga5, Springer, in German.

(14) Hashizume, K. and Abe, N., Development of LiquidFluidized Bed Heat Exchangers, Transactions of the Japan Society of Mechanical Engineers, Series B, Vol. 61, No. 581 (1995), pp. 283-288, in Japanese. 